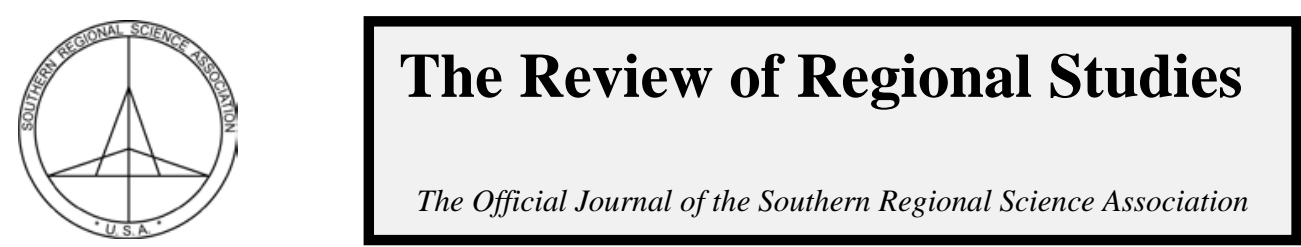

\title{
Targeted Economic Incentives: An Analysis of State Fiscal Policy and Regulatory Conditions*
}

\author{
Peter T. Calcagno and Frank L. Hefner \\ Department of Economics, College of Charleston, USA
}

\begin{abstract}
Economic development incentives by state and local governments have been shown to have little positive economic effect on employment or growth. Using a political economy approach, we investigate the characteristics associated with fiscal conditions and public policies within a state that affect if a state uses targeted economic development incentives. Using data from 1993-2014 from Good Jobs First, we employ a Poisson model to investigate whether states with budget issues, high tax and regulatory burdens, and poorly trained labor are offering targeted incentives to potentially offset costly economic conditions. Our results indicate that unemployment rates, fiscal policy conditions, and individual income tax burden explain the granting of targeted incentives by local governments.

Keywords: state economic incentives, state taxes, targeted incentives, state economic development, state fiscal policy JEL Codes: H25, H71, D72
\end{abstract}

\section{INTRODUCTION}

State and local governments justify the use of targeted economic incentives, such as loan guarantees and tax abatements, by claiming they create jobs and stimulate economic growth. According to Poole et al. (1999), "Governors, mayors, legislators, and council members justify these public investments on the grounds that private-sector decisions to invest in a community result in jobs, income, and tax revenues that are essential to the economic and social well-being of a community or state” (p. 1). State and local governments may use targeted incentives to attract a private firm to a new location, to help support or expand an existing business, or to prevent a company from relocating to another city or state.

While the use of these targeted economic incentives policies is widespread among state and local governments, many scholars and policy makers have repeatedly questioned their efficacy. The literature has demonstrated that these targeted incentives do little if anything to promote economic growth, reduce unemployment, or increase personal income. The question then is why would states pursue these policies that extract revenue from their coffers with little economic return?

Public choice theory offers one explanation. Political benefits exist for politicians who are trying to maximize either votes or tax revenue (Calcagno and Hefner, 2007; Jensen, Malesky, and Walsh, 2015). We argue there is another aspect to this political economy story consistent with

\footnotetext{
* Acknowledgements. We would like to thank the Mercatus Center for funding this research and the participants of the 2017 Southern Regional Science Association meetings for helpful comments.

Peter T. Calcagno and Frank L. Hefner are Professors of Economics at the College of Charleston, Charleston, SC 29424. Corresponding Author: Peter T. Calcagno. E-mail: calacagnop@cofc.edu
}

(C) Southern Regional Science Association 2018.

ISSN 1553-0892, 0048-749X (online)

www.srsa.org/rrs 
McCormick and Tollison (1981) of government as an interest group. State governments create public policies with high tax and regulatory burdens that are costly to businesses, but do not want to reform these policies. Fernandez and Rodrik (1991) argue that when economic reforms have uncertainty as to the distributional gains and losses there is a bias toward the status quo. Thus, we argue that rather than reforming various aspects of fiscal and public policy that could improve economic efficiency, government officials offer firms targeted incentives. The transference of wealth to concentrated firms from disorganized taxpayers has potentially lower political costs than reform. Our hypothesis is that states with costly fiscal policy and factor characteristics, including high tax burdens, regulatory costs, and poorly trained labor, are offering these incentive packages to firms in part to offset the otherwise negative economic conditions. ${ }^{1}$ Thuronyi (1988) makes a similar argument that governments replace tax expenditures with subsidy programs. Targeted development incentives may compensate in part for locational characteristics that make a state's economic policies and climate unattractive. Thus, if we can help to identify the conditions that lead to the offering of these targeted incentives then perhaps we can better address the real underlying issues.

In addition to not achieving their stated goals, these incentive programs may also encourage rent-seeking behavior leading to a host of unintended and undesirable consequences. This rentseeking behavior takes the form of firms employing resources to lobby for tax breaks and other subsidies that add to owners' profits, which can result in a bidding war between two or more state and or local governments that increases the value of the incentive packages and rents the firm can extract from these government agencies. Baumol (1990) notes that entrepreneurial individuals have a choice to devote their labor efforts toward either private sector wealth creation, or toward securing wealth redistribution through the political and legal processes (e.g., lobbying and lawsuits). State governments offering targeted incentives encourages the latter.

Studies by Bennett and DiLorenzo (1983), Esinger (1989), Buss (1999a, 2001), Ellis and Rogers (2000), Saiz (2001), Calcagno and Hefner (2007), Bartik (2005), and Jensen, et al. (2015) point out that there are clear political benefits for using targeted financial incentives. Dewar (1998), Buss (1999a, 1999b), Wiewel (1999), Finkle (1999), Calcagno and Hefner (2009), and Coyne and Moberg (2014) argue that while the mainstream literature on targeted incentives acknowledges they might have a political component, the mainstream research fails to recognize that targeting industries may well be an inefficient allocation of resources.

Industries seeking preferential treatment dominate the political process because votertaxpayers have very little incentive to be well informed about the costs associated with these economic incentive programs or to create any means of organized opposition. The jobs 'created' at a new plant are easily visible to the state or local community; they will not see the jobs that are lost elsewhere in the economy due to the higher tax burdens imposed on other businesses and consumers. Nor do they see the scarce resources that this political process is allocating away from productive ventures. Resources that could produce real output and growth, which firms instead spend lobbying government officials to obtain these favors (Hicks and Shughart, 2007).

The purpose of this paper is to examine the political, economic, and regulatory costs state governments impose to determine if they can explain firms receiving a megadeal. A megadeal is

\footnotetext{
${ }^{1}$ One can think of locational characteristics as falling into three categories: 1) immutable such as a port or mountainous terrain, 2) current policy environment, or 3) quality of factor inputs such as human capital. While the first may matter to the firms making decisions, our focus in this paper is on types two and three.
}

(C) Southern Regional Science Association 2018. 
defined by the organization Good Jobs First as a firm receiving \$75 million or more in targeted incentives. ${ }^{2}$ We use data on megadeals from 1993-2014 across states. Using a Poisson and negative binomial regression analysis, we investigate whether states with fiscal, tax, and regulatory policies that are costly to firms are more likely to offer a megadeal. The rest of the paper is organized as follows. Section 2 provides background on the literature of economic development incentives. Section 3 presents the data. Section 4 offers analysis and results and the final section offers concluding remarks.

\section{BACKGROUND}

The subject of state governments targeting industries using economic development incentives raises important questions regarding economic growth and development, which requires us to examine whether the economic benefits of these targeted economic incentives are worth the economic costs. Whether or not state development incentives lead to real job creation and economic growth has been the subject of much debate among economic scholars. The economic literature abounds with research studies that have examined a variety of programs across the U.S. at both the state and local level.

Economists and policy makers have argued that competition among states to entice companies through targeted incentives provides no net gain to the U.S. economy. "From the states' point of view each may appear better off competing for particular businesses, but the overall economy ends up with less of both private and public goods than if such competition was prohibited" (Burnstein and Rolnick, 1995, p. 7). ${ }^{4}$ These studies suggest that economists have long doubted the efficacy of using state targeted incentives to induce mobile firms (Esinger 1989). Economists have found the evidence associated with the issue of tax and other development incentives generating economic growth to be unconvincing (Buss 1999a, 1999b, 2001). What follows are the findings in the literature on the effects of these policies on state economic growth, job creation, tax revenues, and the rent-seeking and corruption that appear to accompany targeted incentives.

\subsection{Growth, Jobs, and Taxes}

Hicks and Shughart (2007) provide a summary of the literature, which has consistently found that targeted tax incentives have little effect anywhere in the U.S. Peters and Fisher (2004)

\footnotetext{
${ }^{2}$ A primary source for economic development data was the National Association of State Development Agencies. However, they no longer host a webpage or report this data. Good Jobs First has created the Subsidy Tracker, which is a searchable national database. Currently, this is the most comprehensive database available on economic incentives. The data has some issues that need to be noted, first it is continuously being added to, and second it reports the full amount of deals even when the deals are extended over multiple years. Harpel (2014) has a detailed discussion about Subsidy Tracker available online at http://www.smartincentives.org/blogs/blog/14754093-good-jobs-first-and-subsidy-tracker-2-0. Several papers have used data from Good Jobs First Data to examine economic incentives including Jensen (2017), Coyne and Moberg (2014), LeRoy (2013), Wang (2015), Alexander and Organ (2015), and Basker (2007).

${ }^{3}$ We need to make a distinction between competition between states related to tax competition or fiscal federalism as discussed in the literature by Brennan and Buchanan (1980), Tiebout (1956), and Oates (2011) and the political competition to attract firms using tax incentives that are targeted only to a specific firm. The former is a desirable form of competition thought to harmonize tax policy and restrain governments, while the latter we argue is wasteful and ineffective.

${ }^{4}$ Mattey and Spiegel (1995) and Bartik (2002) question whether benefits outweigh these costs. Bartik (1994) argued that development incentives provide the greatest benefit to high unemployment areas. However, he notes that state governments often attract firms to areas that have low unemployment, limiting the benefits that a state may receive from these types of incentives. Calcagno and Thompson (2004) found that targeted incentives merely reallocate resources rather than generate real economic growth.
}

(c) Southern Regional Science Association 2018. 
conduct a meta-analysis, of the most commonly cited reviews of this literature arriving at the same conclusion. They conclude, "the most fundamental problem is that many public officials appear to believe that they can influence the course of their state or local economies through incentives and subsidies to a degree far beyond anything supported by even the most optimistic evidence" (Peters and Fisher, 2004, p. 35). Saiz (2001) found no evidence of overall growth in state gross domestic product or employment levels associated with offering financial incentives and finds negative impacts in certain industries. Examining the issue at the aggregate level, Goss and Phillips (1994) found that economic development agency spending has a positive relationship with state employment growth. However, Bingham and Bowen (1994) found evidence suggesting that state spending on economic development revealed no relationship with gross state product.

Supporters of these targeted incentives claim they have one major goal: to create jobs in the state. Gabe and Kraybill (1998), in a study that examines which firms in Ohio receive targeted incentives, found that the number of new jobs promised by the targeted business is the major factor in deciding who receives the incentive. One could argue that this result is due to political versus market decision making. This outcome is consistent with Weingast, Shepsle, and Johnsen (1981), who find that economic costs and benefits are transformed into political costs and benefits leading to economic inefficiencies when benefits are tied to a geographical location.

Hoyt, Jepsen, and Troske (2008) analyzed the impact of incentives on Kentucky's county employment by broadly categorizing incentives as either "tax incentives," "training incentives," or "financing incentives." 5 They found that the impact of Kentucky's economic development incentives is felt in counties that border neighboring states, but not in interior counties. They found that training incentives have a larger positive impact on county employment than tax incentives, but that financing incentives have no statistical relationship with employment in any county. Finally, they found no evidence of spillover effects in adjacent counties.

Property tax incentives have also been found to be ineffective. In Wisconsin, Merriman, Skidmore, and Kashian (2011) found no evidence that tax increment financing (TIF) districts increase aggregate property values in the communities that adopt them. Further, evidence from El Paso indicates that property tax abatements are "not effective at stimulating improvements in gross metropolitan product, residential housing values, personal income, retail sales, or jobs” (Fullerton and Aragones-Zamudio, 2006, p. 86). More recently, Bruce, Deskins, and Rork (2009) argued that the number of tax incentives and non-tax incentives that a state offers has no statistically significant relationship with growth in gross state product, employment, or state personal income.

\subsection{Strategic Rent-seeking and Corruption}

Coyne and Moberg (2014) illustrated a variety of cases that demonstrate targeted tax incentives are a less than desirable policy. They present several justifications state governments offer for providing these incentives, but note that if firms would have located to an area without the economic incentives then state governments cannot really claim that they have created these jobs. Instead, they argue that targeted incentives create a culture of cronyism and rent-seeking.

Rent-seeking firms would certainly take advantage of the possibility of playing state governments against each other where targeted incentives are available. In 1992, BMW announced

\footnotetext{
${ }^{5}$ Targeted incentives are plentiful and the Hoyt, Jepsen and Troske (2008) categories are a broad taxonomy of incentive types: tax incentives would include tax credits and abatements, training incentives involve credits or subsidies for the training of employees, and financing incentives include loan guarantees and bonds.
}

(C) Southern Regional Science Association 2018. 
that it would locate a plant in Greenville County, South Carolina, after a site selection process that ended in a bidding war between Greenville, South Carolina and Omaha, Nebraska. The Chairman of BMW stated the critical factors in the site selection were proximity to an international airport, port, rail, union presence, and the number of time zones between Bonn, Germany and the site (Patrick, 2014). How Nebraska became a potential site is astounding given the absence of a port, among other issues. Fundamentally, the absence of a port is an immutable characteristic that would be difficult to overcome with targeted tax incentives. The initial incentive package from South Carolina was valued at \$35 million (Kurylko, 1992a). However, Nebraska offered a package valued at $\$ 240$ million. South Carolina countered with a package that was estimated to be $\$ 150$ million (Kurylko, 1992b). Patrick concluded that, "Nebraska’s lucrative incentive package served a useful purpose for the company - raising South Carolina's bid from \$35 million to \$150 million” (Patrick, 2016, p.9). ${ }^{6}$ As with any other rent-seeking activity, this process does more than simply transfer wealth from consumers to producers. The process of acquiring the rents results in the whole transaction being a welfare loss to society (Tullock 1967).

If the purpose of targeted tax incentives is to induce a company to locate in a region, then what justification exists for providing additional incentives after the location decision has been made? Firms that extract rents to locate somewhere will continue to attempt to extract additional rents from state and local governments. This is why the rent-seeking literature often models rentseeking contests as "all-pay auctions" in which bidders sequentially bid on a rent and-whether they win or lose-pay every penny that they bid. If firms are spending resources to collect these rents, then these resources are a deadweight loss along with the excess burden created by the transfer from the state. Jansa and Gray (2014) found evidence of what they refer to as a cultural capture hypothesis; increases in business political contributions are positively correlated with state subsidy spending. In addition, a firm that locates in a region due to subsidies is a firm that will either leave when better subsidies are offered by another state or local government or at least threaten to leave in an effort to extract more subsides from the state. Thus, there is a selection bias for targeted economic development incentives to systematically favor "flighty firms," which promotes a culture of cronyism. ${ }^{7}$ Consider the example from the municipality of North Charleston, South Carolina whose City Council voted to reduce business license fees for four companies that were already in the region: Boeing, Daimler Vans Manufacturing, Select Health of SC, and Trident Regional Medical Center (Slade, 2013). These additional incentives demonstrate Buchanan’s (1986) point that once government policy makers open the door to targeted incentives these businesses have an incentive to try and influence the policy to continue to work in their favor. ${ }^{8}$

Good Jobs First tracks incentives offered to industries across the U.S. (Mattera, Traczynka, and LeRoy, 2013). One subset of their list is 'megadeals.' As noted above, they define a megadeal as an incentive package totaling more than $\$ 75$ million from state and local governments. Appendix 1 provides a list of states that have provided megadeals, with multiple firms receiving deals in some states. If the goal of incentives is to recruit industry, then clearly there is no need to

\footnotetext{
${ }^{6}$ As noted earlier, we are not accounting for immutable location characteristics, in part because they are time invariant and would be captured by fixed effects. We would like to account for the competition between the states and deals that are rejected. Unfortunately, this data is not collected anywhere and exists only as anecdotes as described in the text above.

${ }^{7}$ Recently, Kennametal, a firm that had been located in Latrobe, PA for more than 70 years, was awarded \$1 million in incentives by the state of Pennsylvania to move its headquarters to Pittsburgh. The reason for offering these incentives to move the firm's headquarters from one county to another was to keep the company in the state (Gannon and Belko, 2015; Sheehan, 2015).

${ }^{8}$ Since the data from Good Jobs First are aggregated at the state level we cannot capture repeat incentives given to the same firm in our dataset.
}

(c) Southern Regional Science Association 2018. 
offer larger packages to firms already in place. These repeated deals suggest that this is simply rent-seeking by these firms.

In addition to the issues with targeted economic incentives noted above, these incentives may generate greater corruption within a state. Glaeser and Saks (2006) found a weak negative relationship between corruption and economic development in a state. Utilizing the same data as Glaeser and Saks (2006), Felix and Hines (2013) investigated the connection between tax incentives in the form of tax abatements, tax credits, and tax incremental financing arrangements and corruption. They found a positive and statistically significant relationship between offering these incentives and corruption. Felix and Hines (2013) also found that communities in states with less of a culture of corruption tend to avoid offering businesses incentive packages. We do not maintain that tax incentives are structured to promote corruption; however, the manner in which these deals are structured opens the door. In the case of tax incentives for the film industry, a state audit in Iowa found \$26 million in improperly issued tax credits. The state’s former film office director was convicted of falsifying public records. State prosecutors charged five independent filmmakers and a tax credit broker (Verrier, 2015).

Currently, this literature focuses on whether economic incentives lead to positive outcomes, such as growth, jobs, or tax revenue, versus negative effects, such as rent-seeking, inefficiencies, and corruption. Our focus is whether states are offering these targeted incentives as a means of compensating firms for costly locational characteristics, , one of which may be a culture of corruption. Rather than confront policy and location characteristics that impose costs on firms, such as high tax rates, regulatory burdens, or low quality labor, with political reform, state and local government policy makers offer targeted incentives to make up for these deficiencies. Up to this point the literature has not addressed this issue. We fill a gap in the literature that helps to explain why state and local governments along with economic development agencies are able to continue to promote targeted economic development incentives that the economics literature finds overwhelmingly ineffective at best.

\section{DATA}

Data on targeted financial incentives is often difficult to collect as not all agreements are publicly available or transparent. Good Jobs First has attempted to collect this data in the most consistent way possible. However, since almost every state and local government grants some form of incentive, we consider only large incentives packages, "megadeals." As noted above, megadeals are defined by Good Jobs First as those instances when the firm receives \$75 million or more in incentives. ${ }^{9}$ Good Jobs First admits to limits on their data collection; therefore, to avoid any issues with overstated values we used their megadeal data as a threshold to examine whether the incentives were granted or not. ${ }^{10}$ Thus, our approach treats the dependent variable as a count indicating that the state's economic development package has reached the threshold of a megadeal, thus we add up the number of megadeals in a given state in a given year. We examine the

\footnotetext{
${ }^{9}$ http://www.goodjobsfirst.org/

${ }^{10}$ Good Jobs First faces transparency issues in collecting this data as noted above. In addition, megadeals are often multi-year deals, but Good Jobs First reports the full amount in the year announced. By simply counting the megadeal we are merely acknowledging the type of deal without reflecting on the actual dollar amount or the number of years it is supposed to last.
}

(c) Southern Regional Science Association 2018. 
megadeals for the U.S. states over the period 1993-2014 using a Poisson regression. ${ }^{11}$ Full descriptions of the variables in used in our analysis along with their sources can be found in Table 1 and the descriptive statistics are presented in Table 2.

To examine what determines whether a state government offers a megadeal, we examine the economic, political, policy, and labor market conditions that exist within a state. With respect to economic factors, we include the state unemployment rate, Unemployment, which can indicate the condition of an economy and the employability of its labor force. Higher unemployment rates suggest that economic conditions in the state may be challenging. While there can be numerous reasons for high unemployment, we argue that the poor economic conditions consistent with high unemployment rates will lead a state to offer more targeted incentives in the form of a megadeal. Fiscal conditions of a state may also affect the offering of megadeals. To measure state fiscal conditions, we follow Calcagno and Lopez (2012) in using the ratio of $G / T$ where $G$ is total state government expenditures relative to $T$, the state's own-source tax revenues. This variable measures how much a state government spends, including intergovernmental transfers, for every tax dollar collected from its own in-state tax base. Higher values of $G / T$ could reflect a state's ability to extract intergovernmental revenues, it could instead indicate state deficit spending, or some combination of both. Hou and Smith $(2006,2010)$ argue that all balanced budget rules are not the same and that only the most stringent of the rules are actually binding. Similarly, Poterba (1995) argues that weak budget rules have no impact on balancing the state budget. In addition, Sobel and Crowley (2014) argue that receiving large federal grants can later lead to future tax increases. Thus, we argue that states that tend to have a higher $G / T$ may be more likely to offer megadeals due to their poor fiscal conditions, or in the hope of improving fiscal conditions.

To capture the political conditions of a state, we include the following variables. First, Corruption is the number of public officials convicted of a corruption charge by state per 1,000,000 of the population. This measure has been used by Glaeser and Saks (2006) to reflect the culture of corruption in a state. As noted in section two, Felix and Hines (2013) find a positive and statistically significant relationship between offering incentives and corruption. Thus, we control for the culture of corruption and have similar expectations as to our findings. We consider the degree to which a single party may control the state. Roubini et al. (1989) and Roubini and Sachs (1989) develop an index for measuring divided government or political cohesion (DGI). They code the data between 0 and 2 based on coalitions within the government. Similarly, we code our data based on cohesion of political party. However, since we are using state data, we follow the divided government definitions of Calcagno and Escaleras (2007) and Alt and Lowry (1994, 2000). The index is constructed using the following values: 0 Unified Government, 1 Split Legislature Government, and 2 Split Branch Government. We have no reason to consider targeted incentive to be a partisan issue as parties on both sides of the political spectrum have approved them. However, divided government can be slower to make fiscal adjustments and can create gridlock. Therefore, this measure indicates the ease with which political officials can create legislation and spend funds, which might affect the willingness to offer megadeals. Thus, the more divided the government is the less likely the government is to act and this could lead to fewer megadeals.

\footnotetext{
${ }^{11}$ Our data does not include Nebraska since we attempt to look at divided government as a variable in the model. Nebraska does not have a bicameral legislature and therefore we cannot measure divided government in the same way we can for the other states. In addition, the U.S. Census state and local government finance section for 2001 and 2003 statistics are available only in a national summary by type of government, and by level, there are no state by state statistics. The state figures are available through other data sources, but local government figures by state are unavailable.
}

(c) Southern Regional Science Association 2018. 
Table 1: Variable Descriptions and Sources

\begin{tabular}{|c|c|c|}
\hline Variable & Description & Source \\
\hline Megadeal & $\begin{array}{l}\text { Count of granted megadeals. } \$ 75 \\
\text { million or more in incentives }\end{array}$ & Good Jobs First \\
\hline Unemployment & State Unemployment Rate in Percent & $\begin{array}{l}\text { Federal Reserve Bank of } \\
\text { St. Louis, FRED }\end{array}$ \\
\hline$G / T$ & $\begin{array}{l}\text { Ratio of State Total Expenditures to } \\
\text { State Own-Source Tax Revenues }\end{array}$ & $\begin{array}{l}\text { State and Local } \\
\text { Government Finances, } \\
\text { U.S. Census }\end{array}$ \\
\hline Corruption & $\begin{array}{l}\text { Public officials convicted of corruption } \\
\text { per 1,000,000 individuals }\end{array}$ & $\begin{array}{l}\text { U.S. Department of } \\
\text { Justice }\end{array}$ \\
\hline$D G I$ & $\begin{array}{l}\text { Divided Government Index scaled from } \\
0 \text { - } 2 \text { indicating the degree of divided } \\
\text { government } 0=\text { unified; } 1=\text { split } \\
\text { legislature; and } 2=\text { split branch }\end{array}$ & $\begin{array}{l}\text { Authors calculations from } \\
\text { the Book of the States }\end{array}$ \\
\hline Decentralization & $\begin{array}{l}\text { Ratio of Local Expenditures to State and } \\
\text { Local Expenditures }\end{array}$ & $\begin{array}{l}\text { State and Local } \\
\text { Government Finances, } \\
\text { U.S. Census }\end{array}$ \\
\hline Income & $\begin{array}{l}\text { State Income Tax Burden; ratio of } \\
\text { income tax and personal income }\end{array}$ & $\begin{array}{l}\text { State and Local } \\
\text { Government Finances, } \\
\text { U.S. Census, Bureau of } \\
\text { Economic Analysis }\end{array}$ \\
\hline Corporate & $\begin{array}{l}\text { State Corporate Tax Burden; ratio of } \\
\text { corporate income tax and personal } \\
\text { income }\end{array}$ & $\begin{array}{l}\text { State and Local } \\
\text { Government Finances, } \\
\text { U.S. Census, Bureau of } \\
\text { Economic Analysis }\end{array}$ \\
\hline Sales & $\begin{array}{l}\text { State Sales Tax Burden; ratio of sales } \\
\text { and personal income }\end{array}$ & $\begin{array}{l}\text { State and Local } \\
\text { Government Finances, } \\
\text { U.S. Census, Bureau of } \\
\text { Economic Analysis }\end{array}$ \\
\hline Property & $\begin{array}{l}\text { State and Local Property Tax Burden; } \\
\text { ratio of property taxes and personal } \\
\text { income }\end{array}$ & $\begin{array}{l}\text { State and Local } \\
\text { Government Finances, } \\
\text { U.S. Census, Bureau of } \\
\text { Economic Analysis }\end{array}$ \\
\hline Regulation & $\begin{array}{l}\text { State and Local Protective Inspection } \\
\text { Expenditures Burden; ratio regulatory } \\
\text { spending and personal income }\end{array}$ & $\begin{array}{l}\text { State and Local } \\
\text { Government Finances, } \\
\text { U.S. Census, Bureau of } \\
\text { Economic Analysis }\end{array}$ \\
\hline College Degree & $\begin{array}{l}\text { Percent of Population with a College } \\
\text { Degree }\end{array}$ & U.S. Census \\
\hline Labor Freedom & Area 3 Labor Market Regulation Index & $\begin{array}{l}\text { Economic Freedom of } \\
\text { North America Index }\end{array}$ \\
\hline Time & Time trend & Author's Calculation \\
\hline
\end{tabular}


Table 2: Descriptive Statistics

\begin{tabular}{l|c|c|c|c}
\hline \hline Variable & Mean & Std. Dev. & Maximum & Minimum \\
\hline Megadeal & 0.2931 & 0.7435 & 10.0000 & 0.0000 \\
\hline Unemployment & 5.6687 & 1.8812 & 13.8000 & 2.3000 \\
\hline G/T & 1.6432 & 0.2214 & 2.3695 & 0.7230 \\
\hline Corruption & 3.6837 & 4.9078 & 43.5154 & 0.0000 \\
\hline DGI & 0.8163 & 0.8701 & 2.0000 & 0.0000 \\
\hline Decentralization & 0.4259 & 0.0725 & 0.5762 & 0.0001 \\
\hline Income & 0.0196 & 0.0107 & 0.0425 & 0.0000 \\
\hline Corporate & 0.0039 & 0.0036 & 0.0588 & 0.0000 \\
\hline Sales Tax & 0.0305 & 0.0107 & 0.0626 & 0.0056 \\
\hline Property & 0.0307 & 0.0102 & 0.0612 & 0.0101 \\
\hline Regulation & 0.0012 & 0.0041 & 0.1266 & 0.0003 \\
\hline College & 25.3296 & 5.1674 & 40.3000 & 13.0500 \\
\hline Labor Freedom & 6.8692 & 0.6895 & 8.6751 & 4.5963 \\
\hline Time & 11.5 & 6.3472 & 22 & 1 \\
\hline \hline
\end{tabular}

We control for the degree of fiscal decentralization for each state. Decentralization is measured as the share of state and local government spending that local governments undertake. Arguments for a decentralized state focus on the theory of local knowledge through the division of knowledge to solve complex problems (Hayek, 1945). Like Hayek (1945), Oates (1972) argued that consumers of public goods can better assess which goods jurisdictions should provide and can decide in which jurisdiction to live in based on the mix of public goods offered. Thus, fiscal federalism promotes interjurisdictional competition allowing better jurisdiction assignment over public goods, which could improve spending (Tiebout, 1956; Brennan and Buchanan, 1980). Evidence on the effects of decentralization at the state level includes Sobel, Dutta, and Roy (2013), which examined business climate measures for the U.S. states and concluded that decentralization improves business climate. Stansel (2005) argued that decentralization leads to greater economic growth. One can argue that greater decentralization could improve economic institutions and limit the ability of state governments to offer targeted incentive packages. However, the literature on targeted incentives has shown that local governments are as likely to participate in offering targeted incentives as the state government and in many instance state and local governments work together. This creates competition for businesses not only between states, but potentially within a state. Therefore, greater decentralization may not lead to fewer megadeals for a state, but increase them by redirecting control to local governments to be the ones offering the targeted incentives.

The variables that reflect the policy environment are the tax and regulation variables. We include the various tax and regulation measures that can impose costs on firms above and beyond the costs of production. According to Kayne (1999), the effect of direct assistance to firms to develop successful entrepreneurial enterprises have been minor compared to the effects of state tax and regulatory policies that affect everyone in the state. Specifically, high tax rates have been found to create distortions in markets (Harberger, 1962), have negative effects on state growth (Mofidi and Stone, 1990; Poulson and Kaplan, 2008), and reduce entrepreneurial activity (Kreft and Sobel, 2005; Kayne, 1999). We examine four types of taxes that occur at the state and or local 
level, Income is the state personal income tax burden, Corporate is the total state corporate tax burden, Sales is the total state and local sales tax burden, and Property is the state and local property tax burden. All of these measures are tax burdens, which measure the type of tax revenue (e.g. income tax revenue) over the total personal income. It should be noted that Property tends to be primarily local, so again we can potentially access the degree to which the local government policy environment determines megadeals. Zodrow and Mieszkowski (1986) note that local property taxes can have distortionary effects resulting in fewer public goods. States with high tax burdens could be thought to be less desirable locations to firms, ceteris paribus. Higher taxes would impose costs on firm's owners, employees, and customers. To the extent firms might want to avoid states with high tax burdens, they might locate to states with lower tax burdens. We would expect that state governments with higher relative tax burdens might offer targeted tax and economic incentives to attract firms rather than engage in tax reform. As noted above, tax reform can be politically costly and does not have the immediate and visible political benefits of "creating jobs." Our other policy environment variable is state regulatory spending. Following Calcagno and Sobel (2013) and Campbell, Heriot, and Jauregui (2010) we use regulatory spending at the state and local level on the enforcement of regulation, Regulation. We argue that the state direct expenditures are a good proxy for the regulatory environment firm's face. While more spending could mean more regulations or stricter enforcement of existing regulations, it still reflects the regulatory environment in the state. ${ }^{12}$ It is a stylized fact in the literature that higher regulatory burdens increase costs to businesses and can worsen economic performance. Specifically, the literature on regulation has demonstrated that higher levels of regulation are negatively correlated with business activity, entrepreneurship, and economic growth (Djankov et al., 2002; Ardagna and Lusardi, 2008 ; Klapper, Laeven, and Rajan, 2006 ; van Stel, Storey, and Thurik, 2007; Dawson and Seater, 2013). Again, state governments with relatively higher regulatory burdens may be more likely to approve megadeals to attract firms. All nominal variables are converted to real values. ${ }^{13}$

Our final category of characteristics that might affect states offering megadeals involves labor factors. States with attractive labor markets would have potential employees with high levels of human capital. The percentage of the population with a college degree, College, is our proxy for the quality of human capital in the state. States with high levels of college educated individuals are thought to be less likely to offer firms megadeals. The degree to which labor markets are regulated within a state can affect a firm's costs and availability of quality labor. We use the labor market regulation area 3 of the economic freedom index of North America, Labor Freedom, to account for the degree of labor market regulation. ${ }^{14}$ The index is scored between zero and ten, with higher values indicating greater labor market freedom. We suspect that the higher the level of labor market freedom through fewer labor market regulations, the less likely a state government will offer firms megadeals.

\footnotetext{
12 According to the U.S. Census Classification Manual, example activities included in this spending are "[i]nspection of plans, permits, construction, or installations related to buildings, housing, plumbing, electrical systems, gas, air conditioning, boilers, elevators, electric power plant sites, nuclear facilities, weights and measures, etc.; regulation of financial institutions, taxicabs, public service corporations, insurance companies, private utilities (telephone, electric, etc.), and other corporations; licensing, examination, and regulation of professional occupations, including health-related ones like doctors, nurses, barbers, beauticians, etc.; inspection and regulation or working conditions and occupational hazards” (U.S. Census Bureau, 2011). Revenue from the regulation of licensing or permits is not included in this data.

13 The GDP price deflator, base year of 2009, was used to convert nominal to real values.

${ }^{14}$ Area 3 accounts for minimum wage legislation, the percentage of individuals employed by the state government, and union density.
}

(c) Southern Regional Science Association 2018. 
Given the possibility of unobserved, unique local characteristics, or institutions that tend to be relatively constant over time for a given state, we would like to estimate our models with state fixed effects; however, many of the variables in our sample experience little variation across time. We are more concerned with the variation between states as opposed to within the states. Under these circumstances, fixed effects absorb all of the variation between states that we are trying to explain. Instead, we use regional fixed effects which control for the unobserved heterogeneity across regions. We have grouped the states into the nine U.S. Census Regions. Appendix 2 presents the states in each region.

\section{EMPIRICAL ANALYSIS AND RESULTS}

To test our hypothesis that locational characteristics and the policy environment affect whether a state government offers a firm a megadeal, we estimate the following model:

$$
\begin{aligned}
\text { MEGADEAL }_{\mathrm{it}}= & \beta_{0}+\beta_{1} \text { ECONOMIC }_{\mathrm{it}}+\beta_{2} \text { POLITICAL }_{\mathrm{it}}+\beta_{3} \text { POLICY }_{\mathrm{it}}+ \\
& \beta_{4} \text { PACTOR }_{\mathrm{it}}+\beta_{5} \text { REGIONS }_{\mathrm{i}}+\beta_{6} \text { TIME }_{\mathrm{t}}
\end{aligned}
$$

where Megadeal is the count of targeted incentive packages offered over \$75 million that occur in state $i$ at time $t$. We focus on various characteristics within the state that make it potentially a desirable or undesirable place for a firm to locate. We examine locational characteristics in four broad categories: Economic it is a matrix of economic variables including Unemployment and G/T. We include three variables in our Political ${ }_{i t}$ matrix: Corruption, DGI, and Decentralization. The matrix Policy it $_{\text {has }}$ our five key policy environment variables, Income, Corporate, Sales, Property, and Regulation. Factor ${ }_{i t}$ contains variables to reflect the labor inputs College and Labor Freedom. We use the nine U.S. Census Regions in the matrix Regions, and Time is a time trend. Since we are only interested in the number of megadeals a state offers, the dependent variable is a count measure that ranges from zero to ten. We estimate Equation (1) as a Poisson model.

Table 3 column 1 provides the marginal effects of Equation (1). Unemployment is positive and statistically significant at the 5 percent level, and fiscal conditions, $G / T$, is positive and statistically significant at the 10 percent level. These results are consistent with our expectations and suggest that states that have higher unemployment are more likely to offer firms a megadeal. Similarly, if government expenditures are greater than own tax revenue, which implies poor fiscal conditions, perhaps in the form of state shortfalls or the receiving of intergovernmental grants which can increase tax burdens in the future, then state governments have an increased probability of offering a megadeal. ${ }^{15}$ Fiscal conditions of this type have been found to have electoral effects with the incumbent governor's party being punished (Lowry, Alt, and Ferree, 1998). This might suggest that there is political security in offering targeted incentives that offer the impression of improving a state's budget conditions. Of our three political variables, only Decentralization is statistically significant. There is a positive and statically significant relationship at the 1 percent level for decentralization and megadeals. This finding indicates that states that are more fiscally decentralized, allowing local governments to have more control, are more likely to have megadeals. The implication is that local governments are just as likely to engage in offering targeted economic incentives as the state government.

The findings from the first column of Table 3 with respect to our tax and regulation variables are as follows. Of all of the various tax burdens, only the individual income tax is positive

\footnotetext{
${ }^{15}$ We also examine lagged G/T in equation (1). The results remain unchanged and are not reported here, but are available upon request.
}

(c) Southern Regional Science Association 2018. 
Table 3: Marginal Effects Poisson and Negative Binomial Regressions

\begin{tabular}{|c|c|c|}
\hline Variable & $\begin{array}{c}\text { Coefficient } \\
\text { Poisson }\end{array}$ & $\begin{array}{c}\text { Coefficient } \\
\text { Negative Binomial }\end{array}$ \\
\hline Constant & $\begin{array}{c}-6.550316 \\
(1.654706) \\
0.0150607^{* *}\end{array}$ & $\begin{array}{c}-6.770993 \\
(1.837958) \\
0.0114627\end{array}$ \\
\hline Unemployment & $\begin{array}{c}(0.0076821) \\
0.1388467 *\end{array}$ & $\begin{array}{c}(0.0085541) \\
0.1491714^{*}\end{array}$ \\
\hline $\mathrm{G} / \mathrm{T}$ & $\begin{array}{c}(0.0770318) \\
-0.0002965\end{array}$ & $\begin{array}{c}(0.085798) \\
-0.0007599\end{array}$ \\
\hline Corruption & $\begin{array}{c}(0.0028649) \\
0.0178463\end{array}$ & $\begin{array}{c}(0.0031637) \\
0.0136366\end{array}$ \\
\hline DGI & $\begin{array}{c}(0.0138068) \\
0.9024159 * * *\end{array}$ & $\begin{array}{l}(0.0154729) \\
1.006675 * * *\end{array}$ \\
\hline Decentralization & $\begin{array}{c}(0.2672838) \\
2.632111^{*}\end{array}$ & $\begin{array}{c}(0.2993784) \\
3.29264^{* *}\end{array}$ \\
\hline Income & $\begin{array}{c}(1.558966) \\
0.621896\end{array}$ & $\begin{array}{l}(1.710602) \\
0.2646158\end{array}$ \\
\hline Property & $\begin{array}{c}(2.101839) \\
-4.329565\end{array}$ & $\begin{array}{c}(2.353603) \\
-2.858133\end{array}$ \\
\hline Corporate & $\begin{array}{l}(7.412086) \\
0.8194988\end{array}$ & $\begin{array}{c}(8.055633) \\
0.7966634\end{array}$ \\
\hline Sales & $\begin{array}{l}(1.963567) \\
0.8394019\end{array}$ & $\begin{array}{c}(2.146796) \\
-1.518565\end{array}$ \\
\hline Regulation & $\begin{array}{c}(12.40817) \\
0.0004157\end{array}$ & $\begin{array}{c}(17.80978) \\
0.0004954\end{array}$ \\
\hline College & $\begin{array}{c}(0.0046274) \\
-0.0338328\end{array}$ & $\begin{array}{c}(0.0049873) \\
-0.0334413\end{array}$ \\
\hline $\begin{array}{l}\text { Labor Freedom } \\
\text { Time }\end{array}$ & $\begin{array}{c}(0.0307019) \\
0.0748355 * * * \\
(0.0223078) \\
\end{array}$ & $\begin{array}{c}(0.0339957) \\
0.0132278 * * * \\
(0.0039285) \\
\end{array}$ \\
\hline $\begin{array}{l}\text { Regional Fixed Effects } \\
\mathrm{N} \\
\text { Pseudo R-squared } \\
\text { LR } \chi^{2}\end{array}$ & $\begin{array}{c}\text { Yes } \\
928 \\
.18 \\
245.33\end{array}$ & $\begin{array}{c}\text { Yes } \\
928 \\
.14 \\
172.69\end{array}$ \\
\hline
\end{tabular}

Note: Standard errors in parenthesis *** $1 \%$ significance ** $5 \%$ significance * $10 \%$ significance

and significant, at the 10 percent level. One possible reason why Income is significant in states offering megadeals over the other tax burdens is that individual income tax burdens are often the most visible and affect everyone in the state more so than perhaps corporate or property taxes. Thus, state governments that have higher individual income tax burdens are more likely to offer megadeals. We can interpret the marginal effect as for a 1 unit change in the income tax burden, state governments increase the number of megadeals offered by 2 . Regulatory burdens do not appear to matter to state governments when offering megadeals as we anticipated although it is of the expected sign. Finally, our labor factor variables, College and Labor Freedom, are not statistically significant. This might suggest that state policy makers do not take into account the labor market characteristics beyond the unemployment rate when deciding whether to offer a 
megadeal. Our final variable Time is positive and significant at the 1 percent level, which suggests that megadeals have been increasing over time.

\subsection{Robustness Check}

In addition to tax burdens, we attempted to measure the share of taxes paid. We calculated Income, Corporate, Sales, and Property as tax revenues per capita. Our economic conditions of unemployment and fiscal conditions and Decentralization continue to be significant. Among the tax measures, again only Income is statistically significant. We thought that perhaps the overall tax burden, measured as total tax revenue to total personal income, might explain offering a megadeal. Overall, tax burden is not significant, which emphasizes that it is specifically the individual income tax burden that is the relevant tax to state governments offering a megadeal. ${ }^{16}$

Since our dependent variable has many zeros, we also estimated Equation (1) using a Negative Binomial regression. The Negative Binomial and Poisson results are similar, but the Negative Binomial does not require that the mean and the variance are the same. These results are reported in Column 2 of Table 3. Our results are consistent with the Poisson regression and all of the statistically significant variables in that model are still significant, except Unemployment. ${ }^{17}$

\section{CONCLUSION}

State and local governments continue to offer firms megadeals along with other types of targeted development incentives despite the economic literature calling the efficacy of these tools into question. While the literature has focused on the outcome of these policies, we try to explain what state characteristics might encourage state governments to offer a firm a megadeal (an incentive package of $\$ 75$ million or more). We think that a political economy approach to examining these factors may shed light on why targeted tax incentives persist. While political economists have given attention to the political benefits to vote maximizing politicians, we suggest a slightly different political economy view. It is argued that high tax and regulatory burdens can deter economic growth and entrepreneurship. Thus, poor economic conditions including high unemployment, fiscal policy issues, related to both spending and tax burdens, can lead to firms not wanting to locate in a particular state. We argue that rationally self-interested politicians will offer targeted incentives to compensate for what they perceive as negative economic and political conditions of the state. Therefore, we argue that state and local government officials recognizing the political uncertainty of fiscal reform, both budgeting and tax burdens, maintain the status quo and instead use targeted tax incentives to attract firms to their states.

We use a Poisson model for megadeals for the years 1993-2014 and find some evidence to support our hypothesis. State governments with high unemployment rates and government spending in excess of state revenues are more likely to offer firms a megadeal. In addition, state individual income tax burdens lead to a higher probability of offering firms a megadeal. As individual income taxes are the tax that affects the largest group of individuals in the state, this tax burden appears to have the most consistent impact. Finally, local governments are just as likely to offer targeted incentives; therefore, as decentralization increases so does the probability of firms receiving a megadeal. All of this suggests that when political officials perceive fiscal policy

\footnotetext{
${ }^{16}$ These results are not reported, but are available from the authors upon request.

${ }^{17}$ Since our variable is truncated at zero, one can imagine this as a two-part decision to offer a targeted incentive and then how much. Thus, we also ran equation (1) as a Tobit model. Our key results did not change, and therefore we do not report them here. They are available from the authors upon request.
}

(C) Southern Regional Science Association 2018. 
conditions and high individual income tax burden to be costly to firms, they are more willing to offer targeted incentives. Thus, offering targeted incentives in the name of "job creation" is perhaps more advantageous politically than engaging in uncertain policy reform that could make the state's economic policy environment more attractive for firms to locate there.

\section{REFERENCES}

Alexander, Raquel M. and Alexander J. Organ. (2015) “Business Tax Incentives,” Business Horizons, 58, 363-369.

Alt, James and Robert Lowry. (1994) "Divided Government, Fiscal Institutions, and Budget Deficits: Evidence from the States,” American Political Science Review, 88, 811-28.

Alt, James and Robert Lowry. (2000) “A Dynamic Model of State Budget Outcomes under Divided Partisan Government,” Journal of Politics, 62, 1035-69.

Ardagna, Silvia and Annamaria Lusardi. (2008) "Explaining International Differences in Entrepreneurship: The Role of Individual Characteristics and Regulatory Constraints,” National Bureau of Economic Research, Working Paper 14012: Cambridge, Massachusetts.

Basker, Emek. (2007) “The Causes and Consequences of Wal-Mart's Growth,” Journal of Economic Perspectives, 21, 177-198.

Bartik, Timothy J. (1994) “Jobs, Productivity, and Local Development: What Implications does Economic Research have for the Role of Government?,” National Tax Journal, 47, 847861.

Bartik, Timothy J. (2002) "Evaluating the Impacts of Local Economic Development Policies on Local Economic Outcomes: What has been Done and What is Doable?," Upjohn Institute Staff Working Paper 03-89: Kalamazoo: Michigan.

Bartik, Timothy. (2005) “Solving the Problems of Economic Development Incentives,” Growth and Change, 36, 139-166.

Baumol, William, J. (1990) “Entrepreneurship: Productive, Unproductive and Destructive," Journal of Political Economy, 98, 893-921.

Bennett, James, and Thomas DiLorenzo. (1983) Underground Government: The Off-Budget Public Sector. Cato Institute: Washington, DC.

Bingham, Richard D, and William M. Bowen. (1994) "The Performance of State Economic Development Programs: An Impact Evaluation,” Policy Studies Journal, 22, 501-513.

Brennan, Geoffrey, and James M. Buchanan. (1980) The Power to Tax: Analytical Foundations of a Fiscal Constitution. Cambridge University Press: Cambridge, Massachusetts.

Bruce, Donald, John A. Deskins, and Jonathon C. Rork. (2009) “(Small) Business Activity and State Economic Growth: Does Size Matter?,” Regional Studies, 43, 229-245.

Buchanan, James. (1986) “The Constitution of Economic Policy,” in Karl-Göran Mäller (ed.), Nobel Lectures: Economic Sciences 1981-1990.

Burstein, Melvin L. and Arthur J. Rolnick. (1995) "Congress should End the Economic War Among the States,” Federal Reserve Bank of Minneapolis 1994 Annual Report, 9, 3-19. 
Buss, Terry F. (2001) “The Effect of State Tax Incentives on Economic Growth and Firm Location Decisions: An overview of the Literature,” Economic Development Quarterly, 15, 90-105.

Buss, Terry F. (1999a) “The Case Against Targeted Industry Strategies,” Economic Development Quarterly, 13, 339-356.

Buss, Terry F. (1999b) “To Target or Not to Target, That’s the Question: A Response to Wiewel and Finkle,” Economic Development Quarterly, 13, 365-370.

Calcagno, Peter. T and Monica Escaleras. (2007) "Party Alternation, Divided Government, and Fiscal Performance within US States,” Economics of Governance, 8, 111-28.

Calcagno, Peter T. and Henry Thompson. (2004) "State Economic Incentives: Stimulus or Reallocation?,” Public Finance Review, 35, 1-15.

Calcagno, Peter T. and Frank Hefner. (2007) "State Targeting of Business Investment: Does Targeting Increase Corporate Tax Revenue?,” Journal of Regional Analysis and Policy, 37, 90-102.

Calcagno, Peter T. and Frank Hefner. (2009) “South Carolina's Tax Incentives: Costly, Inefficient and Distortionary,” in Peter T. Calcagno (ed.), Unleashing Capitalism: A Prescription for Economic Prosperity in South Carolina. South Carolina Policy Council: Columbia, South Carolina.

Calcagno, Peter T. and Edward J. Lopez. (2012) “Divided we Vote,” Public Choice, 151, 517536.

Calcagno, Peter T., and Russell S. Sobel. (2013) "Regulatory Costs on Entrepreneurship and Establishment Employee Size,” Small Business Economics: An Entrepreneurship Journal, 41, 90-102.

Campbell, Noel D., Kirk Heriot, and Andres Jauregui. (2010) “State Regulatory Spending: Boon or Brake for New Enterprise Creation and Income?,” Economic Development Quarterly, 24, 243-250.

Coyne, Christopher J. and Lotta Moberg. (2014) “The Political Economy of State-Provided Targeted Benefits,” Mercatus Working Paper Series 13-14.

Dawson, John W. and John J. Seater. (2013) "Federal Regulation and Aggregate Economic Growth," Journal of Economic Growth, 18, 137-177.

Dewar, Margaret E. (1998) "Why State and Local Economic Development Programs Cause so Little Economic Development,” Economic Development Quarterly, 12, 68-87.

Djankov, Simeon, Rafael La Porta, Florencio Lopez-de-Silanes, and Andrei Shleifer. (2002) “The Regulation of Entry,” Quarterly Journal of Economics, 117, 1-37.

Ellis, Stephen and Cynthia Rogers. (2000) “Local Economic Development as a Prisoners' Dilemma: The Role of Business Climate,” Review of Regional Studies, 30, 315-330.

Esinger, Peter K. (1989) The Rise of the Entrepreneurial State: State and Local Development Policy in the United States. The University of Wisconsin Press: Madison. Wisconsin.

Felix, Alison R. and James Hines. (2013) "Who Offers Tax-Based Business Development Incentives?,” Journal of Urban Economics, 75, 80-91. 
Fernandez, Raquel and Rodrik, Dani. (1991) "Resistance to Reform: Status Quo Bias in the Presence of Individual-Specific Uncertainty,” American Economic Review, 81, 11461155.

Finkle, Jeffery A. (1999) "The Case Against Targeting Might have been more...Targeted," Economic Development Quarterly, 13, 361-364.

Fullerton, Thomas and Victor Aragones-Zamudio. (2006) "El Paso Property Tax Abatement Ineffectiveness,” International Journal of Business and Public Administration, 3, 79-94.

Gabe, Todd M. and David S. Kraybill. (1998) “Tax Incentive Re-quests and Offers in a State Economic Development Program,” Review of Regional Studies, 28, 1-14.

Gannon, Joyce, and Mark Belko. (2015) "Latrobe-Based Kennamental to Move Headquarters to Pittsburgh,” Available online in September 2018 at http://www.postgazette.com/business/pittsburgh-company-news/2015/09/18/Latrobe-based-Kennametalto-move-headquarters-to-Pittsburgh/stories/201509180314.

Glaeser, Edward L. and Raven E, Saks, (2006) “Corruption in America,” Journal of Public Economics, 90, 1053-1072.

Goss, Earnest P. and Joseph M. Phillips. (1994) "State Employment Growth: The Impact of Taxes and Economic Development Agency Spending,” Growth and Change, 25, 287-300.

Harberger, Arnold C. (1962) "The Incidence of the Corporation Income Tax," Journal of Political Economy, 70, 215-240.

Harpel, Ellen. (2014) “Good Jobs First and Subsidy Tracker 2.0,” Available online in July 2014 at http://www.smartincentives.org/blogs/blog/14754093-good-jobs-first-and-subsidytracker$2-0$.

Hayek, Friedrich A. (1945) “The Use of Knowledge in Society,” American Economic Review, 35, 519-530.

Hicks, Michael J., and William F. Shughart II. (2007) Quit Playing Favorites: Why Business Subsidies Hurt our Economy,” in Russell S. Sobel (ed.), Unleashing Capitalism: Why Prosperity Stops at the West Virginia Border and How to Fix It. Center for Economic Growth, The Public Policy Foundation of West Virginia: Morgantown, West Virginia.

Hou, Yilin, and Daniel L. Smith. (2006) “A Framework for Understanding State Balanced Budget Requirement Systems: Re-examining Distinctive Features and an Operational Definition,” Public Budgeting \& Finance, 26, 22-45.

Hou, Yilin, and Daniel L. Smith. (2010) "Do State Balanced Budget Requirements Matter? Testing Two Explanatory Frameworks,” Public Choice, 145, 57-79.

Hoyt, William, Christopher Jepsen, and Kenneth Troske. (2008) "Business Incentives and Employment: What Incentives Work and Where?,” University of Kentucky, Institute for Federalism and Intergovernmental Relations Working Papers Series 2009-02, 1-40.

Jansa, Joshua M. and Virginia H. Gray. (2014) “The Politics and Economics of Corporate Subsidies in the 21st Century,” APSA 2014 Annual Meeting Paper.

Jensen, Nathan. (2017) “Job Creation and Firm-Specific Location Incentives,” Journal of Public Policy, 37, 85-112.

(c) Southern Regional Science Association 2018. 
Jensen, Nathan M., Edmund J. Malesky, and Matthew Walsh. (2015) "Competing for Global Capital or Local Voters? The Politics of Business Location Incentives," Public Choice, 164, 331-356.

Kayne, Jay. (1999). "State Entrepreneurship Policies and Programs.” Kaufman Center for Entrepreneurship Leadership at the Ewing Marion Kauffman Foundation: Kansas City, Missouri.

Klapper, Leora, Luc Laeven, and Raghuram Rajan. (2006) "Entry Regulation as a Barrier to Entrepreneurship,” Journal of Financial Economics, 82, 591-629.

Kreft, Steven and Sobel, Russell S. (2005) "Public Policy, Entrepreneurship, and Economic Freedom,” Cato Journal, 25, 595-616.

Kurylko, Diana. (1992a) “BMW Narrows Site Selection to S. Carolina, Nebraska,” Automotive News, May, 18.

Kurylko, Diana. (1992b) “BMW Plant in Review,” Automotive News, June, 15.

LeRoy, Greg. (2013) "The Future of Economic Development Subsidies," Economic Development Journal, 12, 35-39.

Lowry, Robert C., James E. Alt, and Karen E. Ferree. (1998) “Fiscal Policy Outcomes and Electoral Accountability in American States,” American Political Science Review, 92,759_ 774.

Mattera, Philip, Kasia Traczynka, and Greg LeRoy. (2013) “The Largest Economic Development Subsidy Packages Ever Awarded by State and Local Governments in the United States," Good Jobs First.: Washington, DC.

Mattey, Joe and Mark M. Spiegel. (1995) “Is State and Local Competition for Firms Harmful?,” Federal Reserve Bank of San Francisco Weekly Letter 95-26.

McCormick, Robert E. and Robert D. Tollison. (1981) Politicians. Legislation and the Economy: An Inquiry into the Interest-Group Theory of Government. Springer: Netherlands.

Merriman, David, Mark Skidmore, and Russ Kashian. (2011) “Do Tax Increment Finance Districts Stimulate Growth in Real Estate Values?,” Real Estate Economics, 39, 221-250.

Mofidi, Alaeddin and Joe Stone. (1990) “Do State and Local Taxes Affect State Growth?,” Review of Economics and Statistics, 72, 686-691.

Oates, Wallace E. (1972) Fiscal Federalism. Harcourt Brace Jonanovitch: New York.

Oates, Wallace E. (2011) Fiscal Federalism. Paperback ed. Elgar: Cheltenham, UK.

Patrick, Carlianne. (2014) “Does Increasing Available Non-Tax Economic Development Incentives result in More Jobs,” National Tax Journal, 67, 351-386.

Patrick, Carlianne. (2016) "Identifying the Local Economic Impact Development Effects of Million Dollar Facilities,” Economic Inquiry, 54, 1737-1762.

Peters, Alan and Peter Fisher. (2004) "The Failures of Economic Development Incentives," Journal of the American Planning Association, 70, 27-37.

Poole, Kenneth E., George A. Erickecek, Donald T. Iannone, Nancy McCrea, and Pofen Salem. (1999) “Evaluating Business Development Incentives,” U.S. Department of Commerce

(c) Southern Regional Science Association 2018. 
Economic Development Administration: National Association of State Development Agencies.

Poterba, James M. (1995) "Balanced Budget Rules and Fiscal Policy: Evidence from the State. (A New Agenda - Old Constraints),” National Tax Journal, 48, 329-336.

Poulson, Barry W. and Jules G. Kaplan. (2008) “State Income Taxes and Economic Growth,” Cato Journal, 28, 53-71.

Roubini, Nouriel and Jeffrey Sachs. (1989) "Political and Economic Determinants of Budget Deficits in the Industrial Democracies,” European Economics Review, 33, 903-38.

Roubini, Nouriel, Jeffrey Sachs, Seppo Honkapohja, and Daniel Cohen. (1989) "Government Spending and Budget Deficits in the Industrial Countries,” Economic Policy, 4, 99-132.

Saiz, Martin. (2001) "Using Program Attributes to Measure and Evaluate State Economic Development Strategies,” Economic Development Quarterly, 15, 45-57.

Slade, David. (2013) “Tax Break for Big Business,” The Post and Courier. July 6, A1-A8.

Sheehan, Andy. (2015) “Kennametal Moving from Westmoreland Co. to Hazelwood,” CBS Pittsburg KDKA, October, 15.

Sobel, Russell S. and George R. Crowley. (2014) “Do Intergovernmental Grants Create Ratchets in State and Local Taxes?,” Public Choice, 158, 167-187.

Sobel, Russell S., Nabamita Dutta, and Sanjukta Roy. (2013) “Does Fiscal Decentralization Result in a Better Business Climate?,” Applied Economics Letters, 20, 84-91.

Stansel, Dean. (2005) “Local Decentralization and Local Economic Growth: A Cross-Sectional Examination of US Metropolitan Areas,” Journal of Urban Economics, 57, 55-72.

Tiebout, Charles M. (1956) “A Pure Theory of Local Expenditures,” Journal of Political Economy, 64, 416-424.

Thuronyi, Victor. (1988) “Tax Expenditures: A Reassessment,” Duke Law Journal, 6, 1155-1206.

Tullock, Gordon. (1967) "The Welfare Costs of Tariffs, Monopolies, and Theft," Economic Inquiry, 5, 224-232.

van Stel, André, David J. Storey, and A. Roy Thurik. (2007) “The Effects of Business Regulations on Nascent and Young Business Entrepreneurship,” Small Business Economics, 28, 171186.

Verrier, Richard. (2015) “Iowa Film Tax Credit Program Racked by Scandal,” Available online in September 2015 at http://articles.latimes.com/2011/jan/19/business/la-fi-ct-onlocation20110119.

Wang, Jai. (2015) “Do Economic Development Incentives Crowd Out Public Expenditures in U.S. States?,” Paper presented at the American Economic Association, Boston, Massachusetts.

Weingast, Barry R., Kenneth A. Shepsle, and Christopher Johnsen. (1981) "The Political Economy of Benefits and Costs: A Neoclassical Approach to Distributive Politics," Journal of Political Economy, 89, 642-664. 
Wiewel, Wim. (1999) "Policy Research in an Imperfect World: Response to Terry F. Buss the Case Against Targeted Industry Strategies,” Economic Development Quarterly, 13, 357360.

Zodorow, George R. and Peter Mieszkowski. (1986) "Pigou, Tiebout, Property Taxation and the Underprovision of Local Public Goods,” Journal of Urban Economics, 19, 356-370. 
Appendix 1: State Megadeals 1993-2014

\begin{tabular}{|c|c|c|}
\hline State & Number of Megadeals & Total Dollar Value (2009 \$) \\
\hline AK & 1 & $\$ 108,667,141$ \\
\hline $\mathrm{AL}$ & 14 & $\$ 3,417,142,658$ \\
\hline AR & 2 & $\$ 214,214,578$ \\
\hline $\mathrm{AZ}$ & 2 & $\$ 211,207,532$ \\
\hline $\mathrm{CA}$ & 4 & $\$ 1,347,951,343$ \\
\hline $\mathrm{CO}$ & 1 & $\$ 290,396,585$ \\
\hline CT & 11 & $\$ 1,758,059,539$ \\
\hline $\mathrm{DE}$ & 1 & $\$ 222,330,473$ \\
\hline FL & 9 & $\$ 2,002,047,691$ \\
\hline GA & 6 & $\$ 995,753,587$ \\
\hline IA & 7 & $\$ 681,779,440$ \\
\hline ID & 1 & $\$ 278,085,642$ \\
\hline IL & 5 & $\$ 654,227,553$ \\
\hline IN & 8 & $\$ 981,537,483$ \\
\hline KS & 4 & $\$ 450,564,965$ \\
\hline KY & 10 & $\$ 1,257,210,957$ \\
\hline LA & 22 & $\$ 9,591,976,012$ \\
\hline MA & 3 & $\$ 238,664,985$ \\
\hline MD & 2 & $\$ 573,379,478$ \\
\hline ME & 2 & $\$ 411,990,325$ \\
\hline MI & 31 & $\$ 10,294,509,691$ \\
\hline MN & 3 & $\$ 852,165,069$ \\
\hline MO & 14 & $\$ 4,085,464,102$ \\
\hline MS & 9 & $\$ 2,559,359,328$ \\
\hline NC & 9 & $\$ 1,753,498,511$ \\
\hline $\mathrm{NE}$ & 1 & $\$ 53,690,020$ \\
\hline NJ & 21 & $\$ 2,937,093,707$ \\
\hline NM & 6 & $\$ 4,278,363,929$ \\
\hline NY & 24 & $\$ 11,675,626,846$ \\
\hline $\mathrm{OH}$ & 18 & $\$ 2,108,835,505$ \\
\hline OK & 2 & $\$ 199,173,138$ \\
\hline OR & 8 & $\$ 5,508,234,983$ \\
\hline PA & 2 & $\$ 516,445,816$ \\
\hline RI & 2 & $\$ 256,639,459$ \\
\hline $\mathrm{SC}$ & 9 & $\$ 1,871,093,149$ \\
\hline TN & 15 & $\$ 3,195,179,624$ \\
\hline TX & 14 & $\$ 3,416,508,723$ \\
\hline UT & 2 & $\$ 253,284,542$ \\
\hline VA & 3 & $\$ 250,332,884$ \\
\hline WA & 2 & $\$ 11,878,072,626$ \\
\hline WI & 3 & $\$ 252,932,938$ \\
\hline $\mathrm{WV}$ & 2 & $\$ 240,439,170$ \\
\hline
\end{tabular}

(c) Southern Regional Science Association 2018. 
Appendix 2: U.S. Census Regions used for Fixed Effects

\begin{tabular}{|c|c|}
\hline New England & South Atlantic \\
\hline Connecticut & Delaware \\
\hline Maine & Florida \\
\hline Massachusetts & Georgia \\
\hline New Hampshire & Maryland \\
\hline Rhode Island & North Carolina \\
\hline \multirow[t]{2}{*}{ Vermont } & South Carolina \\
\hline & Virginia \\
\hline Middle Atlantic & West Virginia \\
\hline \multicolumn{2}{|l|}{ New Jersey } \\
\hline New York & East South Central \\
\hline \multirow[t]{2}{*}{ Pennsylvania } & Alabama \\
\hline & Kentucky \\
\hline East North Central & Mississippi \\
\hline Indiana & Tennessee \\
\hline \multicolumn{2}{|l|}{ Illinois } \\
\hline Michigan & West South Central \\
\hline Ohio & Arkansas \\
\hline \multirow[t]{2}{*}{ Wisconsin } & Louisiana \\
\hline & Oklahoma \\
\hline West North Central & Texas \\
\hline \multicolumn{2}{|l|}{ Iowa } \\
\hline Kansas & Mountain \\
\hline Minnesota & Arizona \\
\hline Missouri & Colorado \\
\hline Nebraska & Idaho \\
\hline North Dakota & New Mexico \\
\hline \multirow[t]{11}{*}{ South Dakota } & Montana \\
\hline & Utah \\
\hline & Nevada \\
\hline & Wyoming \\
\hline & Arizona \\
\hline & Pacific \\
\hline & Alaska \\
\hline & California \\
\hline & Hawaii \\
\hline & Oregon \\
\hline & Washington \\
\hline
\end{tabular}

(C) Southern Regional Science Association 2018. 